\title{
Advertising and Public Relations: Challenges and Implications
}

\section{Nurbek Achilov*}

Deputy Chairman, Eurasian Economic Club of Scientists Association, Kazakhstan

\begin{abstract}
The paper overviews theories and present challenging issues of advertising and public relations and their implications in the context of classified components and factors. It is important to evaluate these two subjects on similarities and differences, and their challenges and implications from positive and negative points. It helps to outline key ideas and perspectives for further studies of topics.
\end{abstract}

Keywords: Advertising; Public relations; Challenges of advertising and public relations; Implications of advertising and public relations; Instruments of advertising and public relations; Promotion mix

\section{Introduction}

Advertising and Public Relations start their mission from focusing on feelings of their audiences to find a client or to change its relations, attitude or thinking. These two subjects have many similarities, but they are different for whom the information intended to reach and how it should affect the target audience. Until recently, advertising was an instrument to inform the audience to find clients. Today, advertising becomes more targeted, cost-efficient and search oriented. To illustrate, Google, Yandex and other search engines offer unique advertising opportunities to access clients worldwide, which no other media can offer for available budget and for 24 hours a day.

Concerning public relations, previously it was an instrument to work and communicate effectively with public. Today, public relations covers areas related to leading and changing public views and thinking. For example, Facebook, LinkedIn, Twitter and other social media allow organizations not only access, communicate with the public but also tackle key issues, access new social groups and constantly involve them to change their thinking, attitudes and character. As the first step to define the challenging issues and implications of the two subjects, it is necessary to overview the instruments of advertising and public relations from angle of historical changes. Therefore, Table 1 outlines major instruments of advertising and public relations of the past, present and in the future.

Table 1 shows main instruments of advertising and public relations. Analyzing the Table, one can conclude that advertising and public relations are gradually changing from mass to target media, and in future, it will change to interactive target media. This is one of the challenging issues from technological point. Companies, which will be first to acquire those technologies will have competitive advantage and can grow their audiences enormously. Analysis supports that the effects of changing technology are of great concern to the advertising and PR industries [1]. The review of literature and papers will provide a broader scope of knowledge and understanding of advertising and PR effects on people, their behavior and the future. According to marketing theory [2], advertising and public relations is a part of the promotion mix, which relates to persuading audiences to buy products, concepts and ideas. Here [2], advertising defined as any paid of nonpersonal presentation and promotion of ideas, goods or services whereas public relations defined as nonpaid, nonpersonal stimulation of demand for a product, service or business unit by planning significant news about it or a favorable presentation of it in the media.

However, which is the best tool to sell products, advertising or public relation? There is no simple answer as they are part of the marketing field which requires many other factors to be taken into account. Bittlingmayer G [3] suggests that when looking at the problems the firms faces in promoting their goods, one can understand why advertising used in some cases and not in others. It is true that it depends on how big is the company, what is the budget etc.

The Table 2 shows the outcome of preliminary evaluation of the differences of advertising and public relations on key components, classified from personal experience.

\begin{tabular}{|c|c|c|}
\hline & Advertising & Public Relations \\
\hline $\begin{array}{l}\text { Past } \\
\text { (from } 1930 \\
\text { to 2000) }\end{array}$ & $\begin{array}{l}\text {-TV } \\
\text {-Radio } \\
\text {-Newspaper } \\
\text {-Booklets/Catalogs } \\
\text {-Boards } \\
\text {-Telephone } \\
\text {-Outdoor advertising }\end{array}$ & $\begin{array}{l}\text {-TV interviews/broadcast } \\
\text {-Radio interviews/broadcast } \\
\text {-Newspaper articles } \\
\text {-Press-conferences } \\
\text {-Telephone communication } \\
\text {-PR campaigns (offline) } \\
\text {-Public speaking (offline) }\end{array}$ \\
\hline $\begin{array}{l}\text { ICT Era } \\
\text { (from 2000- } \\
2025 \text { ) }\end{array}$ & $\begin{array}{l}\text {-Internet } \\
\text {-Web-sites } \\
\text {-Emails } \\
\text {-Online Catalogs } \\
\text {-Search Engine } \\
\text {-Social Media } \\
\text {-Mobile/Smart phone }\end{array}$ & $\begin{array}{l}\text {-Web content (articles, video, interviews etc.) } \\
\text {-Web interactions/streaming } \\
\text {-Multimedia press relations } \\
\text {-Social Media Communication } \\
\text {-Email communication } \\
\text {-Mobile/Smart phone communication } \\
\text {-Online Communication/News/Contests/ } \\
\text { Feedbacks } \\
\text {-Online Communication Campaigns } \\
\text {-Online Televised Public Speaking and } \\
\text { Communication }\end{array}$ \\
\hline $\begin{array}{l}\text { Future } \\
\text { (from 2025- } \\
2050 \text { ) }\end{array}$ & $\begin{array}{l}\text {-Super smart phones } \\
\text {-Electronics and gadgets } \\
\text { with internet access } \\
\text {-Social Media } \\
\text {-Search Engines } \\
\text {-Holographic/Interactive } \\
\text { smart technologies/ } \\
\text { gadgets for advertising }\end{array}$ & $\begin{array}{l}\text {-Super smart phones } \\
\text {-Interactive Social Media Communication } \\
\text {-Individual and corporate online channels } \\
\text { (video, content, polls etc.) } \\
\text {-Holographic/Interactive smart } \\
\text { technologies/gadgets for communication }\end{array}$ \\
\hline
\end{tabular}

Table 1: Instruments of advertising and public relations (past, present, future).

*Corresponding author: Achilov N, Professor, Deputy Chairman, Executive Body of Eurasian Economic Club of Scientists Association, Shymkent, Kazakhstan, Tel: +77019402978; E-mail: nurbek2020@gmail.com

Received August 14, 2016; Accepted August 22, 2016; Published August 30 2016

Citation: Achilov N (2016) Advertising and Public Relations: Challenges and Implications. J Mass Communicat Journalism S2: 001. doi: 10.4172/2165-7912. S2-001

Copyright: (C) 2016 Achilov N. This is an open-access article distributed under the terms of the Creative Commons Attribution License, which permits unrestricted use, distribution, and reproduction in any medium, provided the original author and source are credited. 
Table 2 shows that public relations include broader knowledge of audiences, scope of activities and factors to communicate effectively with target audiences compared to advertising. It is a huge area, which requires many competences and skills to persuade, analyze and build relationships. However, many organizations hire advertising specialist to take the role of public relations. Because many see public relations as an area which help to promote ideas, products or personalities and relate it to distribution of press-releases to the target audiences. It is a wrong perception and probably one of the main reasons why afterwards PR perceived negatively [4]. Advertising specialists cannot be the best PR specialists without training and education. From Table 3 , one can conclude that is a key issue why many organizations fail PR campaigns with their approaches with human resources.

Why advertising and PR are on the agenda of almost all organizations? Why should organizations can apply various other tools?

Now, we can compare advertising and public relations with other instruments of promotion mix to show their advantages. Table 3 compares four elements of promotion mix.

Table 3 shows why advertising and public relations are of the highest priority for organizations. One can see that advertising and $\mathrm{PR}$ are wide in audience scope, which is main factor to reach potential customers. One the other side, only PR can improve organization's image via effective communication on negative information from customers, state bodies etc. Application of PR is also wide and it includes not only business customers but also government, public organization and individuals [5].
The Tables 2 and 4 demonstrates also how important the challenges and implications of the advertising and publics relations to customers, governments, public organizations, individuals and generally to our societies.

After overviewing the technological trends, main components of advertising and public relations and their comparison with elements of promotion mix, the next step is to classify their challenging issues. Table 4 outlines key challenges of advertising and public relations in various areas [6].

From analysis of literature, internet and personal experiences, Table 4 consists of at least 8 challenging issues of advertising and public relations. The Table indicates positive and negative challenges in these areas. From all, the most important issues are the corporate efficiency and development as well as issues related to ethics, transparency and trends. Their implications are so high that it can grow the business instantly or destroy it with only one action or campaign. For example, the one campaign with the highest cost will increase the sales of product many times so that it will increase the market share of the organization and its image at the same time. However, in a case when low budget advertising will create negative feelings in segments of the organization, which had high market share, advertising can cause spreading of negative word of mouth and end business only because of cultural perception, content or ethical issues [7].

Taking challenges as key factor for further study, the following Table 5 shows positive and negative implications of advertising and public relations actions.

Based on factors analyzed above, Table 5 focuses on 6 major

\begin{tabular}{|c|c|c|}
\hline & Advertising & Public Relations \\
\hline Purpose & Inform to sell & $\begin{array}{c}\text { Communicate to sell, solve, lead, change or build relationship, image, } \\
\text { reputation }\end{array}$ \\
\hline Structures in organizations & Business & Business, Politics, Government, NGO and etc. \\
\hline Objects and Areas & Products and Services, Organization, Ideas, Projects & $\begin{array}{c}\text { All, including resources, HR, other clients, policies, procedures, } \\
\text { processes, R\&D etc. }\end{array}$ \\
\hline Content for audience & Spots, banners, video, messages, announcement etc. & Messages, Articles, Presentations, Dialogues, Discussions, Interviews etc. \\
\hline Value for organization & Profitability & Profitability, Image and Reputation \\
\hline Delivery of Content & Paid [2] & Nonpaid [2] \\
\hline Expenditures & Design, Production, Distribution & Design, Production \\
\hline Business Audience & Perspective, New and Loyal Customers & $\begin{array}{l}\text { All type of customers, including unsatisfied, with problems, complains etc. } \\
\text { Also employees, partners, suppliers and distributors }\end{array}$ \\
\hline Non-business Audience & No & $\begin{array}{c}\text { Government, Media, Competitors, Public Organizations, Supporters, } \\
\text { Opponents etc. }\end{array}$ \\
\hline Key factor & $\begin{array}{l}\text { Quality of Advertising, Key Message and Creativity, Time, } \\
\text { Place, Appropriateness and Trustworthiness of Ads }\end{array}$ & $\begin{array}{l}\text { Key Message, Effectiveness of Communication Skills, Time, Place, } \\
\text { Appropriateness and Trustworthiness of Content and Communication }\end{array}$ \\
\hline
\end{tabular}

Table 2: Differences of advertising and public relations.

\begin{tabular}{|c|c|c|c|c|}
\hline & Advertising & Public Relations & Personal selling & Sales Promotion \\
\hline Purpose & Inform and sell & Communicate and sell & Personal oral communication & Stimulate and sell \\
\hline Costs & High & Medium & Medium & Low \\
\hline Cost Structure & Distribution & Campaign & Access, Transport, Telephone & Coupons, Billboards, Information list \\
\hline Scope of audience & Wide & Wide & Individual, local & $\begin{array}{l}\text { Loyal or new customers of the } \\
\text { store, shop, brand }\end{array}$ \\
\hline Objects & $\begin{array}{l}\text { Existing, New or future } \\
\text { products }\end{array}$ & $\begin{array}{l}\text { Products, Employees, Partners, Media, } \\
\text { Stakeholders, etc. Negative information, } \\
\text { crisis, complains }\end{array}$ & Existing products & $\begin{array}{l}\text { Existing products, products which } \\
\text { expire or with low demand/sales }\end{array}$ \\
\hline Key Factor & Ads content, Channel & $\begin{array}{l}\text { PR content, Channel, Communication } \\
\text { skills }\end{array}$ & $\begin{array}{l}\text { Place, price, Advantages of product, } \\
\text { Presentation skills }\end{array}$ & Price, place \\
\hline Application & $\begin{array}{l}\text { Business, Public, Government } \\
\text { (Social Ads) }\end{array}$ & $\begin{array}{l}\text { Business, Government, Public, } \\
\text { Individuals }\end{array}$ & Business, Public & Business, Public \\
\hline
\end{tabular}

Table 3: Comparison of promotion mix elements. 
Citation: Achilov N (2016) Advertising and Public Relations: Challenges and Implications. J Mass Communicat Journalism S2: 001. doi: 10.4172/21657912.S2-001

\begin{tabular}{|c|c|c|c|}
\hline \multirow[t]{2}{*}{$\#$} & \multirow[t]{2}{*}{ Areas } & \multicolumn{2}{|c|}{ Challenges } \\
\hline & & Positive & Negative \\
\hline 1 & Technology & $\begin{array}{l}\text {-Better targeting; -Better interaction; -Increasing audiences with } \\
\text { minimal budgets and quickly }\end{array}$ & $\begin{array}{l}\text {-Fear of technology [4] } \\
\text {-Requires resources and time to handle new technology }\end{array}$ \\
\hline 2 & $\begin{array}{l}\text { Web, Social Media, } \\
\text { Channels }\end{array}$ & $\begin{array}{l}\text {-Offer many tools to inform and communicate } \\
\text {-Digital and Interactive TV channels can stimulate new growth }\end{array}$ & $\begin{array}{l}\text {-Require creativity and new approaches on a constant base } \\
\text {-Require consistency, interactive and appropriate } \\
\text { information to succeed }\end{array}$ \\
\hline 3 & $\begin{array}{l}\text { Regulations [10] and } \\
\text { Trends }\end{array}$ & $\begin{array}{l}\text {-There is a room for new ideas and innovations that can stimulate } \\
\text { advertising and public communication }\end{array}$ & $\begin{array}{l}\text {-Advertising regulations take time to learn and adapt the } \\
\text { content [10] -The decreasing role of traditional journalism [6] }\end{array}$ \\
\hline 4 & Audience & $\begin{array}{l}\text {-Have many options for interaction; } \\
\text {-Easy to involve audiences } \\
\text {-Hyper-Personalized Content [6] } \\
\text {-Opportunity to access international and global audiences easily } \\
\text {-Real Time Crisis/Problem monitoring [6] }\end{array}$ & $\begin{array}{l}\text {-Negative experiences make it difficult to attract and } \\
\text { communicate with audiences } \\
\text {-Many audiences can create content which form negative } \\
\text { perception in target audiences } \\
\text {-Language and cultural differences can fail campaigns [10] }\end{array}$ \\
\hline 5 & Intellectual Rights Issues & $\begin{array}{l}\text {-Opportunity to patent and communicate the same brand for all } \\
\text { markets }\end{array}$ & $\begin{array}{l}\text {-Easy to copy, distribute materials and products to profit by } \\
\text { third sides }\end{array}$ \\
\hline 6 & $\begin{array}{l}\text { Ethical issues }[2,5] \text { and } \\
\text { Transparency [6] }\end{array}$ & $\begin{array}{l}\text {-Promote universal corporate culture and ethics of the organization } \\
\text {-Demonstrate image and transparency of a organization via PR } \\
\text { materials and information } \\
\text {-Increase credibility of the organization and its products [7] }\end{array}$ & $\begin{array}{l}\text {-Using materials in own way for many unethical purposes } \\
\text {-Advertising products without informing about low quality, } \\
\text { absent features, harmful effects for people or children [2] } \\
\text {-Using PR to win elections, offend, humiliate or realize } \\
\text { campaigns without benefiting public }\end{array}$ \\
\hline 7 & $\begin{array}{l}\text { Corporate Efficiency and } \\
\text { Development }\end{array}$ & $\begin{array}{l}\text {-Apply PR for effective, integrated approach [6] to grow organization } \\
\text {-Via communication improve products and services for customers } \\
\text {-Balancing budgets using new technologies and its momentum effects } \\
\text { for sales and profitability }\end{array}$ & $\begin{array}{l}\text {-Using advertising and PR only for profiting without } \\
\text { improving and developing organization, its products, } \\
\text { processes etc. } \\
\text {-High spending on advertising and public relations without } \\
\text { positive effect on corporate development, sales or efficiency }\end{array}$ \\
\hline 8 & Learning and Educating & $\begin{array}{l}\text {-Learn new competences and knowledges via Advertising and PR [8] } \\
\text {-Educating HR on new competences and knowledges can improve } \\
\text { adaption to new technologies, audiences and markets }\end{array}$ & $\begin{array}{l}\text {-Leading and Educating require investments and } \\
\text { development of knowledge systems }\end{array}$ \\
\hline
\end{tabular}

Table 4: Challenges of advertising and public relations.

\begin{tabular}{|c|c|c|c|}
\hline \multirow[t]{2}{*}{ \# } & \multirow[t]{2}{*}{ Actions } & \multicolumn{2}{|c|}{ Implications } \\
\hline & & Positive & Negative \\
\hline 1 & Advertising & $\begin{array}{l}\text {-High sales of products via advertising can stimulate investments } \\
\text { in new areas of research and product development, so that it will } \\
\text { stimulate the growth of economy via creating new jobs and ventures } \\
\text {-Positive advertising can create new ideas and inspire people for } \\
\text { creative ideas, new businesses etc. } \\
\text {-Advertising allow to distribute the best corporate values and } \\
\text { cultures so that stimulating many cultures for new living standards, } \\
\text { technologies etc. } \\
\text {-Advertising help inform target audiences or remind them about the } \\
\text { organization } \\
\text {-Social advertising can stimulate people for positive actions to support } \\
\text { and save state or private programs }\end{array}$ & $\begin{array}{l}\text {-Too often ads, create addiction of people for buying } \\
\text { unnecessary products; create ignorance and annoyance if ads } \\
\text { or communication not appropriate or in time } \\
\text {-Advertised harmful products can increase cases of health } \\
\text { problems in society, when a government did not plan in terms } \\
\text { of budgets, HR and resources } \\
\text {-High costs of advertising can hurt organization financial } \\
\text { indicators and growth } \\
\text {-Advertising can hurt perception of people and build their } \\
\text { negative feeling to countries, products, languages, attributes, } \\
\text { people with other race, ethnicity etc. if the content is not } \\
\text { appropriate and well adapted. As a result, it can fail any } \\
\text { campaign with a huge cost for the organization }\end{array}$ \\
\hline 2 & $\begin{array}{l}\text { Public Relation } \\
\text { Communication }\end{array}$ & $\begin{array}{l}\text {-PR can resolve corporate, business and customer issues and build } \\
\text { positive relationship with all clients (employees, partners, stakeholders, } \\
\text { media, governments, competitors) which will give better access to wide } \\
\text { audiences in a short period of time } \\
\text {-PR can help customers and audiences better understand the } \\
\text { organization, its next steps and future perspectives } \\
\text {-PR builds trust and loyalty via sensible details and explanations to } \\
\text { spread positive word of mouth }\end{array}$ & $\begin{array}{l}\text {-PR requires constant attention to the audience and effective } \\
\text { communication on a constant base } \\
\text {-High cost of PR without effect can lead to ignorance of PR as } \\
\text { the tool to communicate } \\
\text {-Non-professional PR can lead to negative reaction of } \\
\text { the clients (employees, partners, stakeholders, media, } \\
\text { governments, competitors) that can hurt organization. } \\
\text {-Audiences can experience bad feelings from interaction and } \\
\text { further communication with organization }\end{array}$ \\
\hline 3 & $\begin{array}{l}\text { Building image and } \\
\text { reputation via Ads and } \\
\text { PR }\end{array}$ & $\begin{array}{l}\text { Advertising and PR can build image and reputation of organization so } \\
\text { that audiences know the it well and can trust its products or services }\end{array}$ & $\begin{array}{l}\text { Organizations become very vulnerable to negative word of } \\
\text { mouth, negative information or complaints from customers that } \\
\text { can hurt the business, its image or sales }\end{array}$ \\
\hline 4 & $\begin{array}{l}\text { New technologies of } \\
\text { advertising and PR }\end{array}$ & Improve access, efficiency and communication with audiences & $\begin{array}{l}\text {-Create negative feelings and fear to use, communicate and } \\
\text { trust if organizations do not protect private information or } \\
\text { respond slowly }\end{array}$ \\
\hline 5 & $\begin{array}{l}\text { Usage of Social Media } \\
\text { for Ads and PR }\end{array}$ & $\begin{array}{l}\text {-Help to communicate, grow audiences and interact on various issues } \\
\text {-Increase sells and positive word of mouth easily }\end{array}$ & $\begin{array}{l}\text {-Competitors do benchmarking and access data of clients } \\
\text {-Negative information or complains instantly reach all followers } \\
\text { or friends of organizations }\end{array}$ \\
\hline 6 & Framing [9] & $\begin{array}{l}\text { With professional team, framing helps to understand how people } \\
\text { evaluate information provided via advertising and public relations. } \\
\text { It improves activities and information for sales and effective } \\
\text { communication }\end{array}$ & $\begin{array}{l}\text { It can be difficult for audiences if the framing team will change } \\
\text { and customers will not understand a new team's approaches } \\
\text { and messages. This can stimulate audiences for a new brand, } \\
\text { product, organization }\end{array}$ \\
\hline
\end{tabular}

Table 5: Implications of advertising and public relations. 


\begin{tabular}{|c|c|c|}
\hline \multirow{2}{*}{ Advertising or PR Effect } & \multicolumn{2}{|c|}{ Negative Implications for: } \\
\cline { 2 - 3 } & Producers & Consumers \\
\hline Positive & Low & High \\
\hline Neutral & Low & High \\
\hline Negative & Medium & High \\
\hline Open Truth and Cases & High & High \\
\hline
\end{tabular}

Table 6: Level of negative implication of harmful products and services for producers and consumers.

positive and negative implications. It shows that advertising and public relations require professionalism and special approaches in order to bring positive outcome and effects. Sometimes, it does not matter the amount of budget for advertising and public relations but rather the content or skills, which can draw positive or negative feeling of the potential audience. If information creates a negative feeling in customers, they will try to avoid the organization and its products until they will get convinced that the product is the best in the market. Vice versa, if it creates positive feeling, nothing stops customers from buying or interacting with organization [8].

The worst case is when advertised harmful products with positive effect on customers stimulate sales. If not in short term, but in long term this will hurt customers and it will be late to do anything. However, it depends on many factors when it hurts the organization directly.

Table 6 demonstrate the level of implications of harmful products and services based on effects from advertising and PR.

From Table 6 above, one can see that advertising and PR of harmful products can have different level of negative implications for producers and consumers. When the truth becomes open, the implications are bad for both an organization and those who consumed the products and became sick, for example. The problem is that the negative implications for consumers are high in any case whereas producers will not face any negative implications until it becomes clear that products are harmful [9].

The organization will face negative implications only when harmful effects become open as a truth after negative cases or experiments [10]. The point is that the truth can become open after 5 years or 50 years. Until that time, many changes can happen that it will be difficult to find responsible person or team for producing or advertising the harmful products. From ethical issues, for example, for medical products, it requires regulations for transparency and open research data.
The paper aimed to define not only challenges and implications of advertising and public relations, but also classify them for further evaluation and analysis. The results of this paper calls for further studies and investigations to evaluate many factors and implications of advertising and public relations in detail. In addition, analysis requires in terms of market volume of advertising and PR, number of companies and key media channels in terms of audience, scope, convenience etc.

Moreover, it is necessary to do research in areas of future technologies to define trends of advertising and public relations for mid and long term period. From economical point, research and classification of efficiency measurement tools for advertising and public relations will provide better understanding how organizations and companies will perceive these two demanding areas for informing and communicating with target audiences.

\section{References}

1. Sally D, Lyndon S, Adam V (1996) Competition, strategy, technology and people: The challenges facing PR. International Journal of Advertising 15: 1-4.

2. Boyd HW, Walker OC, Jean-Claude L (1995) Marketing management: a strategic approach with a global orientation. Irwin/McGraw-Hill.

3. Bittlingmayer $\mathrm{G}$ (2008) The concise encyclopedia of economics advertising-2008 [http://www.econlib.org/library/Enc/Advertising.html]. Library of Economics and Liberty. Accessed on: August 13, 2016.

4. James M (2008) A review of the impact of new media on public relations: Challenges for terrain, practice and education. Asia Pacific Public Relations Journal 8: 137-148.

5. Bowen S (2007) Ethics and Public Relations- 2007 [http://www.instituteforpr org/ethics-and-public-relations/] Institute of Public Relations. Accessed on: August 12, 2016

6. Comcowich W (2014) 10 challenges facing public relations right now-2014 [http://www.cyberalert.com/blog/index.php/10-challenges-facing-publicrelations-right-now/] Cyber alert. Accessed on: August 12, 2016.

7. Johnson K (2016) Challenges of Public Relations in the $21^{\text {st }}$ Century-2016 [http:// smallbusiness.chron.com/challenges-public-relations-21st-century-61155. html] The Houston Chronicles. Accessed on: August 12, 2016.

8. Molleda JC (2009) Global Public Relations- 2009 [http://www.instituteforpr.org/ global-public-relations/] Institute of Public Relations. Accessed on: August 12 2016.

9. Hallahan K (1999) Seven models of framing: implications for public relations Journal of public relations research 3: 205-242.

10. Hill WLC (2001) International business: competing in the global marketplace. Irwin/ MacGraw-Hill.

This article was originally published in a special issue, Advertising and 